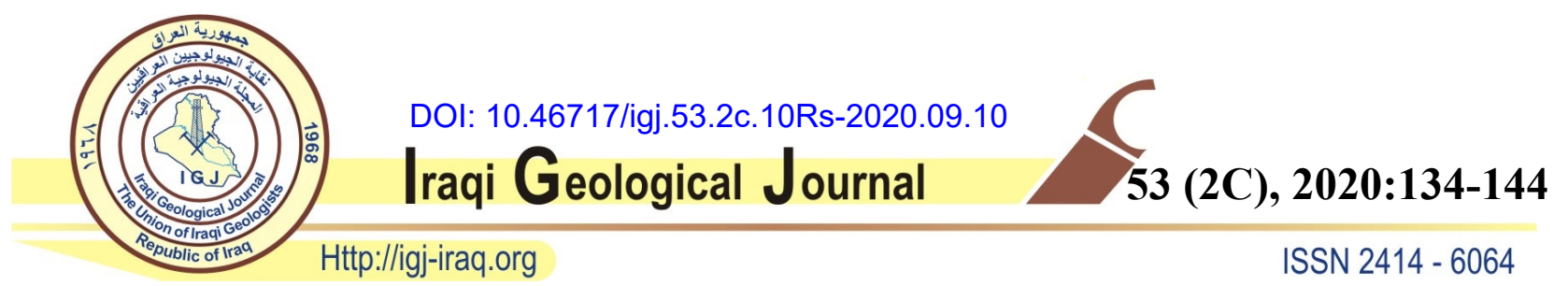

\title{
DETECTED OF GYPSUM SOIL LAYER BY USING 2D AND 3D ELECTRICAL RESISTIVITY IMAGING TECHNIQUES IN UNIVERSITY OF ANBAR, IRAQ
}

\author{
${ }^{1}$ Ali M. Abed, ${ }^{2}$ Ahmed S. Al-Zubedi, and ${ }^{3}$ Zaidoon T. Abdulrazzaq" \\ ${ }^{1}$ Departments of Applied Geology, College of Science, University of Anbar, Iraq \\ ${ }^{2}$ General Commission for Groundwater, Iraq \\ ${ }^{3}$ Directorate of Space and Communications, Ministry of Science and Technology, Iraq \\ "E-mail: zaidoon.taha@live.com \\ Received: 16 January 2020; accepted: 3 April 2020
}

\begin{abstract}
The 2D electrical resistivity imaging survey was implemented in the area located within the University of Anbar, using a dipole-dipole array to detect the gypsum soil layer. This survey was done along seven analogous $2 \mathrm{D}$ lines adjacency in $\mathrm{E}-\mathrm{W}$ direction, then the data of all $2 \mathrm{D}$ lines were merged to produce $3 D$ resistivity imaging models. Laboratory tests of three soil samples in the survey area were analyzed and correlated with data obtained from $2 D$ imaging to determine gypsum content in the soil. Our results of $2 \mathrm{D}$ and $3 \mathrm{D}$ imaging models show that the gypsum soil layer thickness is $2.53 \mathrm{~m}$ approximately, and it is characterized by high differences in the resistivity values in the range of 50 to more than $400 \Omega \mathrm{m}$. This difference is generally caused by high inhomogeneities in the hardness of soil components, while the test results show the gypsum content in the samples equal to 213, 232, and $211 \mathrm{~g} / \mathrm{kg}$ respectively, and it is indicative of that the soil consists of a high content of gypsum. The correlation between these results is indicative of the area is unstable and can be led to a differential settlement that causes cracks and collapses of the constructions.
\end{abstract}

Keywords: Gypsum soil; ERI techniques; Dipole-dipole array; Laboratory tests

\section{INTRODUCTION}

Gypsum soil is one of the most important materials that directly affect construction stability especially when groundwater level lies near the earth's surface. This effect appears when gypsum dissolved in water leaving cavities and voids that lead to a differential settlement that causes cracks and collapses of buildings (Al-Mamoori, 2017). Othman et al., 2020 mentioned that the 
common-ion effect of sulfate ion in acidic solution $\left(0.0001 \mathrm{~N} \mathrm{H}_{2} \mathrm{SO}_{4}\right)$ decrease the dissolution or solubility (which represents the concentration of $\mathrm{Ca}^{2+} \& \mathrm{~S}^{2-}$ ) of gypsum, while the presence of $\mathrm{Na}^{+}$and $\mathrm{OH}^{-}$in alkaline solution $(0.0001 \mathrm{~N} \mathrm{NaOH})$ different from the ions of gypsum itself generally makes the gypsum more soluble. In Iraq, many buildings have suffered diverse patterns of cracks and deformations generated primarily from the increase of the supportive gypsum soils to water (Al-Saoudi et al., 2013). Any engineering site needs an extensive investigation of the site soil gypsum layers to decide whether the soil is suitable to the proposed project or not, (AlMamoori, 2017). Thi Nu et al., 2020 mentioned that the increase in salt content in soft soil causes a decrease in undrained shear strength and an increase in compression index, liquid limit of soft soil. Resistivity methods, especially 2D and 3D electrical resistivity imaging (ERI) techniques are very useful in this situation. Application of these techniques for geotechnical site characterization is very useful to determine the subsurface geology and the subsurface structures such as cavities, voids, soil stability (Auken et al., 2006: Sudha et al., 2009; Wisén et al., 2012; Mohammad, 2012; Loke et al., 2013; Thabit and Abed, 2014; Abdelwahab, 2013; Hassan and Nsaif, 2016; Amini and Ramazi, 2017; Hassan et al., 2018 and Aziz et al., 2019).

The presence of gypsum soils in dry and semi-dry areas in the engineering construction sites brings significant geotechnical and geo-environmental problems, (Kadhim, 2014). The determination of these problems is important to facilitate the proposed construction site concerning the shallow and deep foundations (Hassan et al., 2018). The expansion of the creation of new departments and colleges within the University of Anbar, which is characterized by the presence of gypsum soils, led to conduct of engineering investigations to determine the thickness and extension of gypsum soils. Usually drilling boreholes to conduct chemical and physical tests for different depths are commonly implemented for geotechnical site investigations. However, these tests are expensive and limited to a point (Al-Ebdaa, 2016). In comparison, ERI techniques are less expensive and can be implemented along profiles to obtain 2D and 3D resistivity imaging models. So, in this study, 2D and 3D ERI techniques are adopted to detect the gypsum soil layer.

\section{SITE DESCRIPTION}

The study area is located within Anbar University at the south and southwest Ramadi city, between the longitude of $43^{\circ} 15^{\prime} 40^{\prime \prime}-43^{\circ} 15^{\prime} 44^{\prime \prime} \mathrm{E}$, and latitude of $33^{\circ} 24^{\prime} 15^{\prime \prime}-33^{\circ} 24^{\prime} 17^{\prime \prime} \mathrm{N}$ (Fig. 1). It includes many buildings of the colleges and some new construction projects. The surface soil in this area covers by Fatha Formation (Middle Miocene), which is exposed in large 
parts of the western desert areas; it is divided into four members. The lower member is developed east of the Euphrates River, and in a narrow strip along the south bank of the river, it is consisting of green marl, limestone and gypsum. The upper member is developed east of the Euphrates River, especially along Al-Tharthar Lake. The thickness of this member ranges from 20-30 m. It consists of marl, limestone, gypsum, claystone, siltstone, and sandstone. Nfayil member is exposed only south of the Euphrates River and cover large parts of the western desert areas. The beds consist of green marl and limestone. The second cycle contains oyster, which is a diagnostic feature of the Nfayil beds. The thickness ranges from 5-18 $\mathrm{m}$. The clastic member is developed at the southeastern part only. It is consisting of marl, siltstone, claystone and fine sandstone with secondary gypsum in rhythmic nature, the thickness of this member ranges from 10-15 m. Thin limestone bed may occur in the lowermost part (Jassim and Buday, 2006).

The old buildings were built in the university without taking into consideration engineering studies that deal with the presence of the gypsum soil layer. This soil is characterized by the presence of secondary gypsum that causes differential settlement of buildings as shown in Fig. 2 . Most civil projects did not care about this effect of this layer not in the university but even inside the city of Ramadi, as evidenced by what happened a few days ago on Omar Bin Abdul Aziz Street from the subsidence of a hole with a diameter of more than 4 meters (Fig. 3). There is one well nearby study area (200 m depth). The static water level of this well equals to $7 \mathrm{~m}$ and the lithological section of the upper meters shows the presence of gypsum soil with a thickness of 1 $\mathrm{m}$ above the claystone layer of Fatha Formation that extends to a depth of $20 \mathrm{~m}$ (G. C. G. W., 2001), as shown in Fig. 4.

\section{MATERIALS AND METHODS}

The 2D imaging survey was done in the area located within the University of Anbar using the SAS-4000 instrument. This survey was implemented along seven 2D lines in the E-W direction by using the dipole-dipole array (Fig. 5). Each one of the 2D imaging lines consists of 42 electrodes with $2 \mathrm{~m}$ of electrode spacing and a line spacing equal to $4 \mathrm{~m}$. The survey was carried out by this array because most studies, that have been carried out to determine which of arrays respond best in imaging shallow targets in different situations, indicated that the higher resolution and high sensitivity to geologic detail for shallow investigation offered by the dipole-dipole array (Al-Zubedi, 2015). 


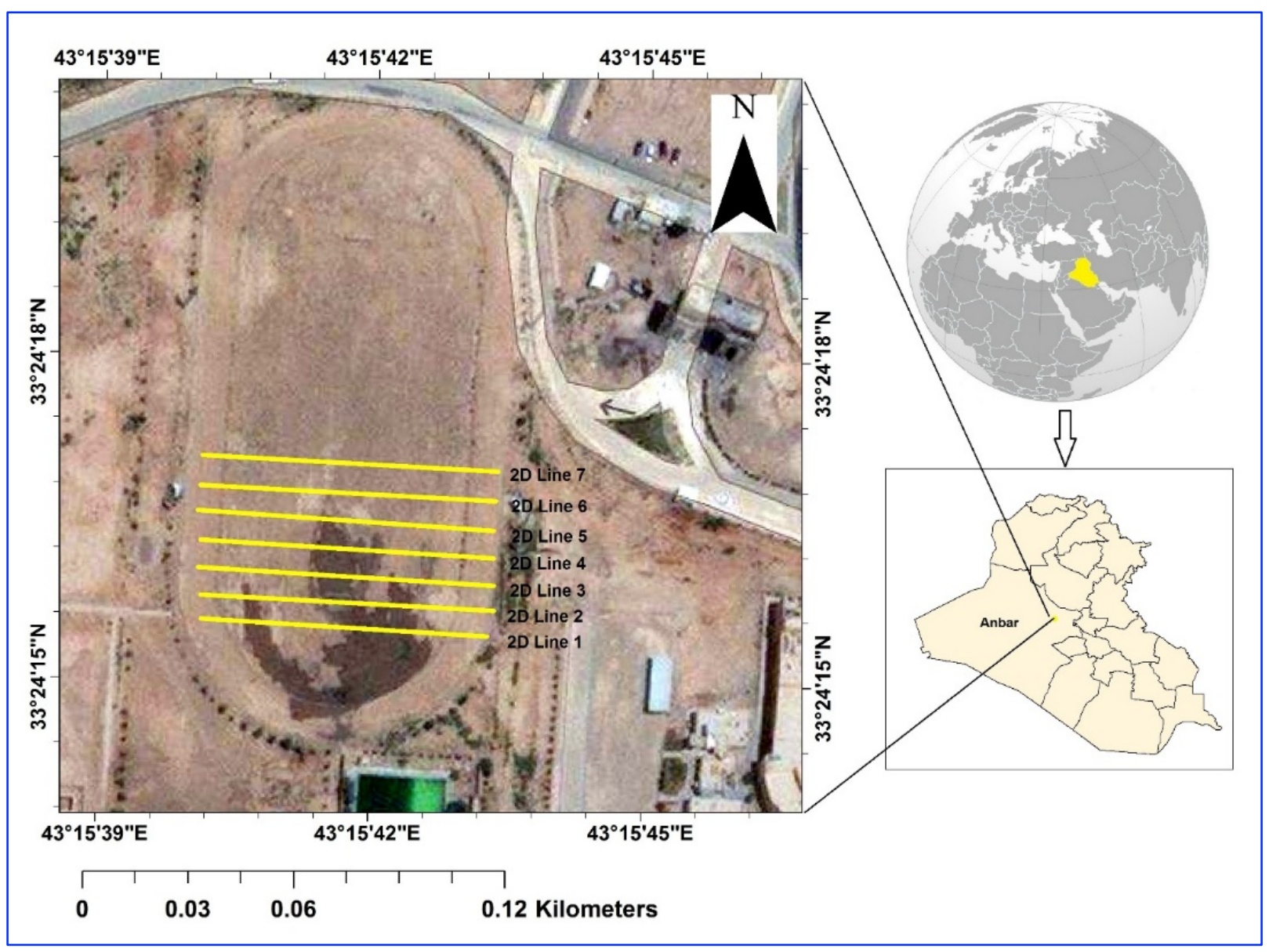

Fig. 1. Location map of the study area

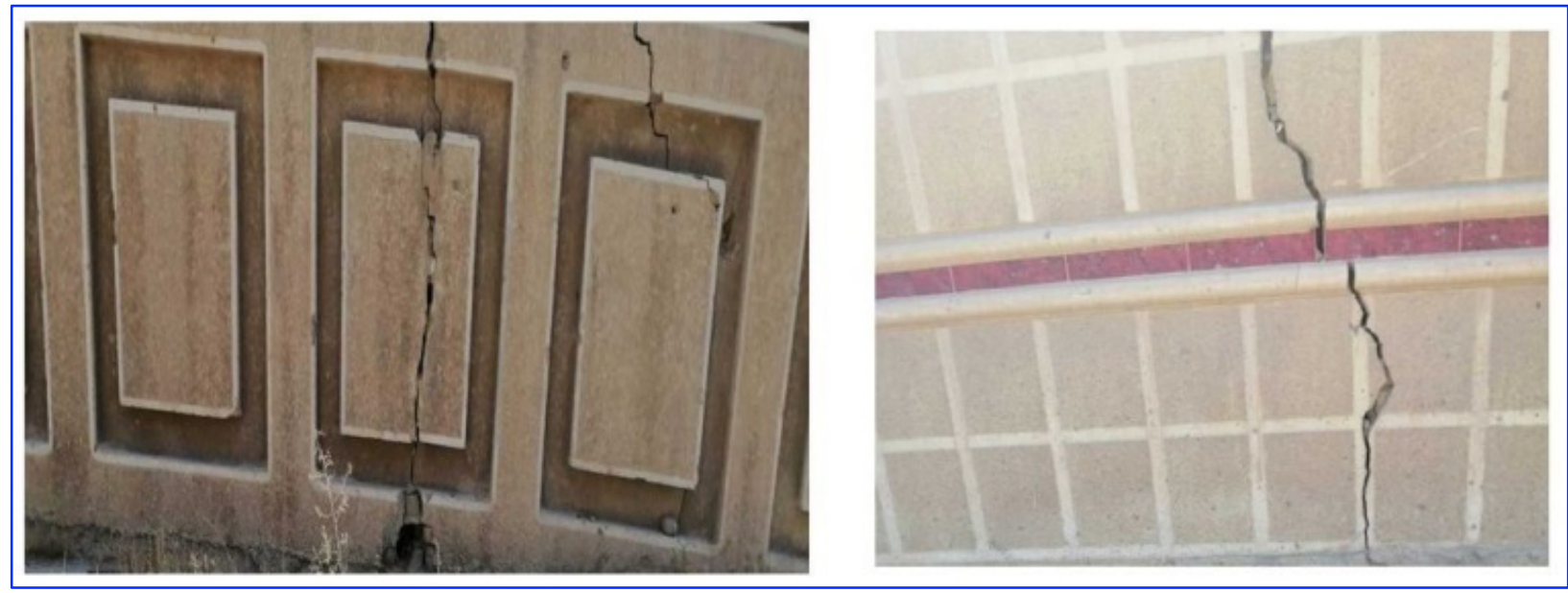

Fig. 2. Cracks in the walls of buildings 

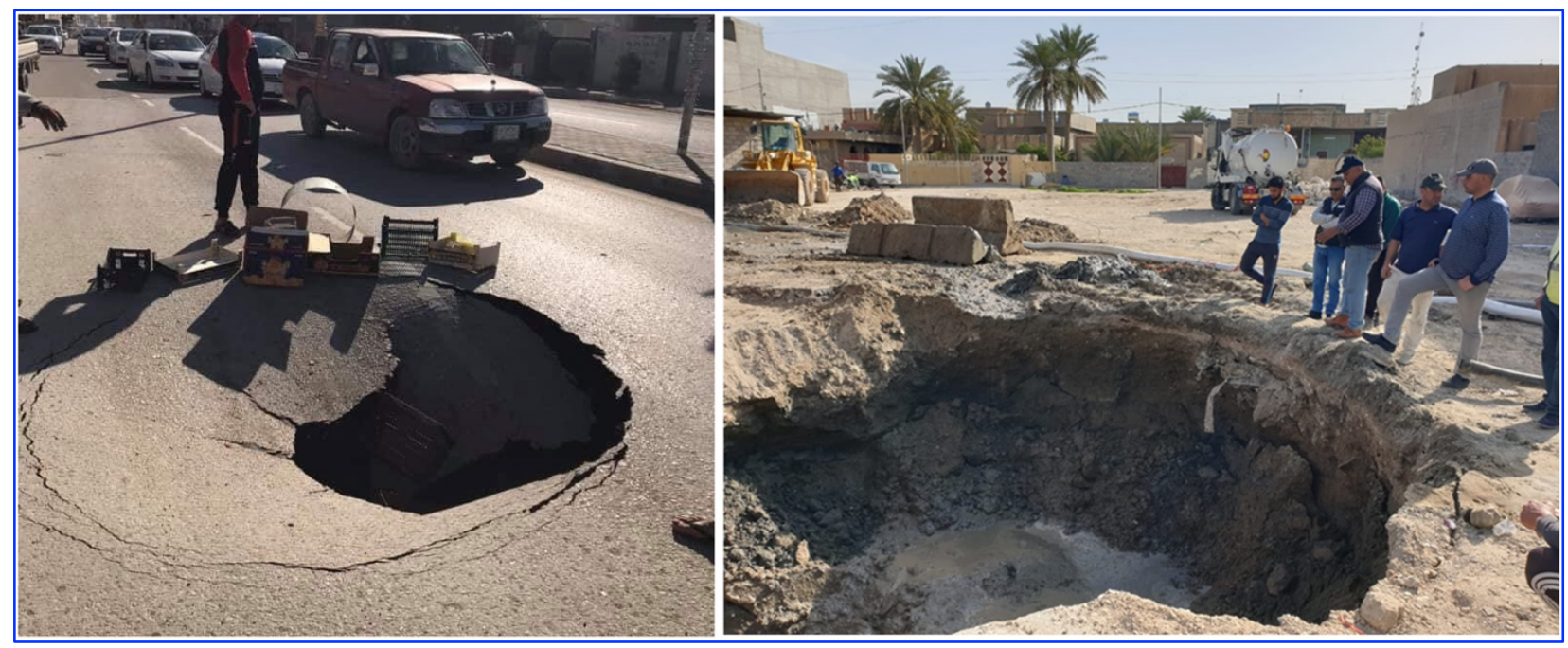

Fig. 3. The subsidence of a hole in Omar bin Abdul Aziz Street within the city of Ramadi

\begin{tabular}{|c|c|c|c|c|c|}
\hline \multicolumn{2}{|c|}{$\begin{array}{c}\text { Depth } \\
\text { (m) }\end{array}$} & \multirow{2}{*}{$\begin{array}{l}\text { Thickness } \\
\text { (m) }\end{array}$} & \multirow[t]{2}{*}{ Brief Description } & \multirow{2}{*}{$\begin{array}{l}\text { Lat : } 33^{\circ} 20^{\prime} 27^{\prime \prime} \mathrm{N} \\
\text { Long : } 43^{\prime} 15^{\prime} 47 \mathrm{E} \\
\text { Elevation : } 57.37 \mathrm{~m}\end{array}$} & \multirow{2}{*}{$\begin{array}{l}\text { BH-CDS-1 } \\
\text { LITHOLOGY }\end{array}$} \\
\hline From & To & & & & \\
\hline 0.0 & 1.5 & 1.5 & Gypsiferous soil and gypsum & & \\
\hline 1.5 & 7.6 & 6.1 & Pale brown claystone & & \\
\hline 7.6 & 15.2 & 7.6 & Claystone with gypsum & & \\
\hline 15.2 & 19.0 & 3.8 & Pinkish pale claystone & & \\
\hline 19.0 & 22.6 & 3.6 & Silty claystone with limestone & & \\
\hline 22.6 & 34.2 & 13.6 & Claystone with siltstone & & \\
\hline 34.2 & 38.0 & 3.8 & Silty gypsiferous siltstone & & \\
\hline 38.0 & 45.3 & 7.3 & Clayey gypsiferous limestone & & \\
\hline 45.3 & 63.9 & 18.6 & White gypsum & & \\
\hline 63.9 & 67.2 & 3.3 & Brown claystone with gypsum & & \\
\hline 67.2 & 71.0 & 3.8 & Green marl & & \\
\hline 71.0 & 74.7 & 3.7 & Gypsum & & \\
\hline 74.7 & 76 & 1.3 & Gypsum with green marl & & \\
\hline 76 & 79.6 & 3.6 & Marly gypsiferous limestone & & \\
\hline 79.6 & 87.3 & 7.7 & White gypsum with marl & & \\
\hline 87.3 & 102.2 & 14.9 & Limestone with gypsum & & $-1=$ \\
\hline 102.2 & 117.2 & 15.0 & Limestone withmarly gypsum & & \\
\hline 117.2 & 138.0 & 20.2 & Marly limestone with gypsum & & \\
\hline 138.0 & 142.5 & 4.5 & Grey marl & & \\
\hline 142.5 & 160.5 & 18 & Grey marl and marly limestne & & \\
\hline 160.5 & 185 & 24.5 & $\begin{array}{l}\text { Marly Limestone with } \\
\text { fossiliferous limestone }\end{array}$ & & \\
\hline 185 & 194 & 9.0 & Chalkylimestone andlimestone & & \\
\hline 194 & 200 & 6.0 & Marly limestone & 200 & \\
\hline
\end{tabular}

Fig. 4. Lithological section of the groundwater well (G. C. G. W., 2001) 
Within the study area, three samples of soil at depths $1 \mathrm{~m}$ were selected in the centers of 2D lines $1,4,7$ respectively, to analyze gypsum contained and compare it with the results of the 2D imaging survey. Laboratory tests of gypsum soil were carried out in the laboratories of the College of Science, University of Anbar. As an attempt to make a 3D view of the gypsum soil layer, the 2D imaging data were set in one data file as a text to obtained 3D models by using the RES3DINV program and to be used later for inversion processes.

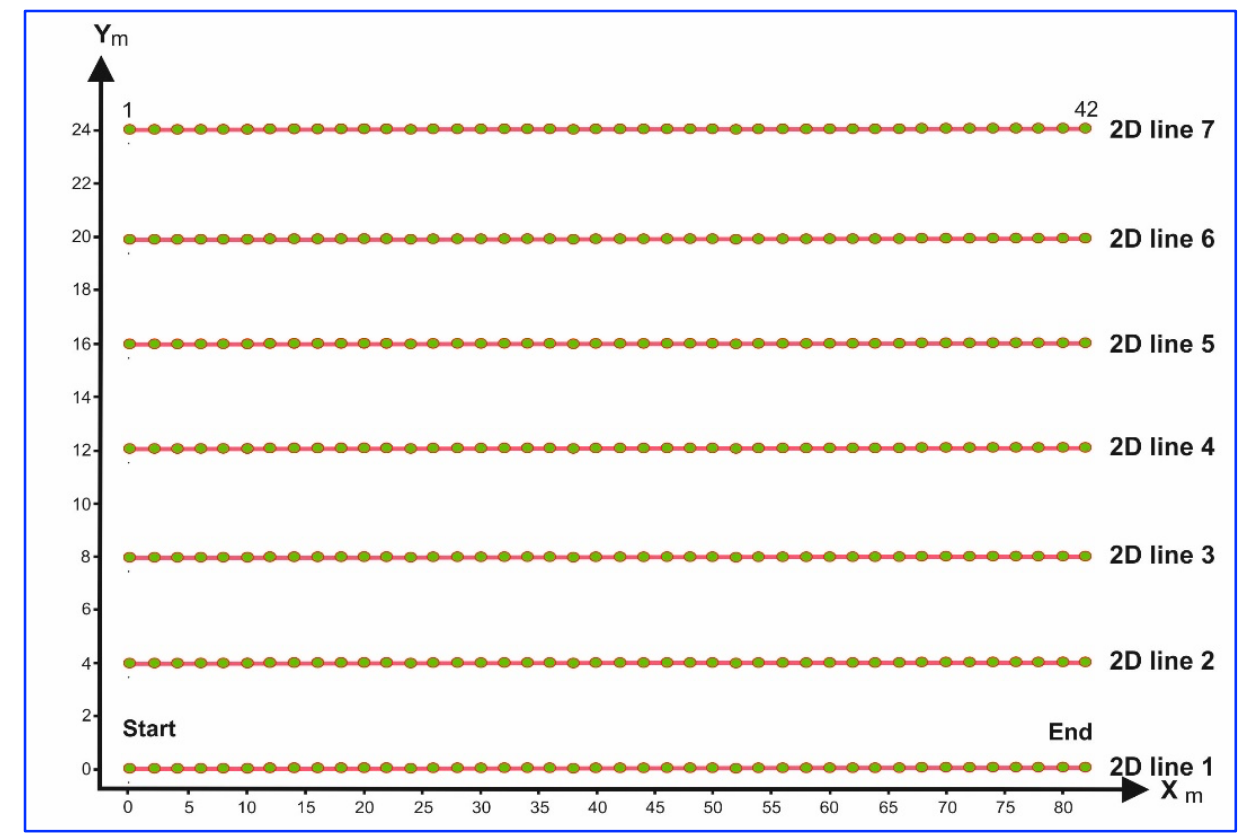

Fig. 5. Data acquirement by a 2D imaging technique

\section{RESULTS AND DISCUSSION}

The 2D imaging data was interpreted via the RES2DINV software, through a robust inversion option. This option is commonly used when the 2D models include sharp boundaries (Claerbout and Muir, 1973; Wolke and Schwetlick, 1988; Olayinka and Yaramanci, 2000 and Loke et al., 2013). The cavities and voids in most cases have sharp geologic boundaries. Therefore, it is used to interpret all 2D ERI data. Interpretation for the inverse models of all 2D imaging lines has distinguished the presence of two resistivity zones. The first one represents a dry surface soil layer and extends to a depth of $2.53 \mathrm{~m}$ approximately (Fig. 6). It is characterized by high differences in the resistivity values in the range of 50 to more than $400 \Omega \mathrm{m}$. This difference is caused by the difference in its components since it consists of sand, silt with secondary gypsum (Makhilif et al., 2019). Besides, the results of laboratory tests show that the gypsum content $\left(\mathrm{CaSO}_{4} . \mathrm{H}_{2} \mathrm{O}\right)$ of three selected samples is equal to 213,232 and $211 \mathrm{~g} / \mathrm{kg}$, respectively. This 
result indicated that the gypsum content is ranged from $21-23 \%$, and it is indicative that the soil consists of high content of gypsum according to testing standard BS 1377: 1990 - Part 3 (soils test methods for civil engineering purposes). However, this layer is not showing any cavities or voids might be due to its' dry and the secondary gypsum did not dissolve by groundwater. However, the lithological section of well (G. C. G. W., 2001) reveals the thickness of this layer equal to $1 \mathrm{~m}$, as shown in Fig. 4, while these models reveal that the layer thickness is equal to $2.53 \mathrm{~m}$ approximately. This means that the surface soil has more thickness in this area.

The second zone appears at a depth $2.53 \mathrm{~m}$ approximately and extends at depth $16.4 \mathrm{~m}$. As well, it has highly varying resistivity to the extent of 0.2 to more than $50 \Omega \mathrm{m}$, which decreases with depth. This zone represents the claystone layer of the Fatha Formation according to G.C.G.W. (2001). The differences between the resistivity values of this zone are possibly caused by the increasing groundwater salinity with depths or the presence of lithological variations in the upper part of this layer. To generate 3D imaging models, we use data obtained in parallel 2D imaging lines. There is one of the most common methods based on combining all 2D data files in a single 3D data file using a text editor. This text file is readable by RES3DINV software (Alzubedi and Thabit, 2016). In this study, it was used to produce 3D inverted models. The horizontal sections of 3D models are presenting a good image of the surface soil extension in all directions $(\mathrm{x}, \mathrm{y}$, and $\mathrm{z}$ ). It reveals the presence of weak zones in the surface soil and the upper part of the claystone layer. These weak zones are clearly shown as spots with highly varying resistivity values in the sections of depths $0-0.80 \mathrm{~m}, 0.80-1.72 \mathrm{~m}, 1.72-2.78 \mathrm{~m}$ and $2.78-3.99 \mathrm{~m}$ (Fig. 7), to reflect the inhomogeneity in the hardness of soil components and the upper part of claystone layer. Concerning the sections of 3D imaging that have depths from 3.99-5.39 to 13.4$16.2 \mathrm{~m}$, it gives an image that is similar to that obtained from the $2 \mathrm{D}$ resistivity imaging, which represents the upper part of claystone layer of the Fatha Formation. The Zondres3d software is used in this study, it is considered as the best option for displaying 3D results as 3D cross-planes and $3 \mathrm{D}$ cube models, (Fig. 8). Both results of 3D cross-planes and 3D cube models have presented a clear image of the changes in the surface and subsurface soil components and the upper part of the claystone layer. It reveals the vertical extension of spots with depth and that reflects the inhomogeneity in the hardness of soil components and the upper part of the claystone layer. 


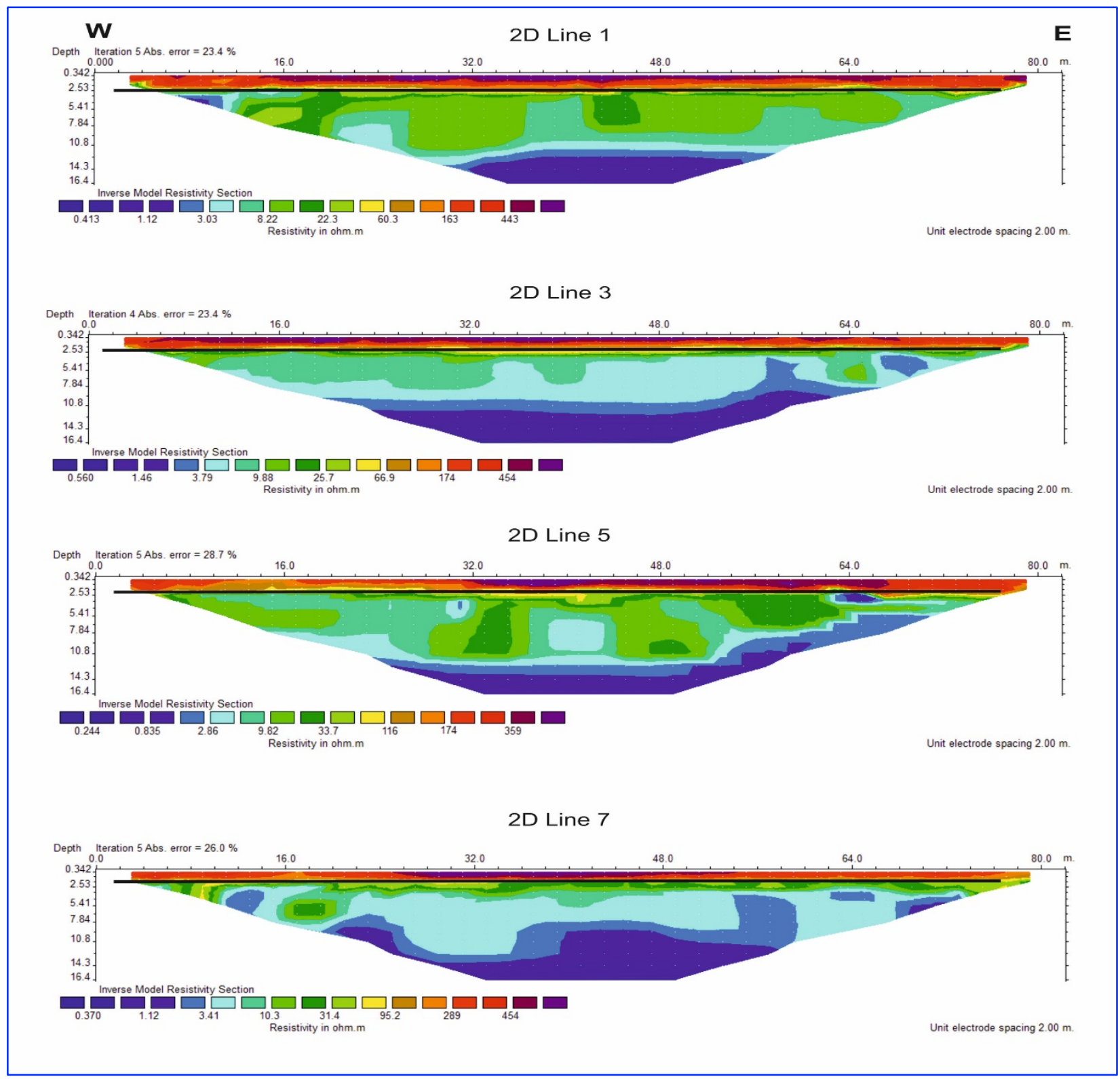

Fig. 6. 2D imaging models for lines 1, 3, 5 and 7

The results of both 2D and 3D resistivity imaging models address approximately the same gypsums soil thickness $2.53 \mathrm{~m}$ in the investigation area and show high inhomogeneity in the hardness of soil components and upper part of the claystone layer. Both 2D and 3D resistivity imaging show large RMS error values of inverted models, and that indicates the investigation area is characterized by high inhomogeneity. This inhomogeneity led to the presence of large resistivity contrast for surface soil components and the upper part of the claystone layer. 


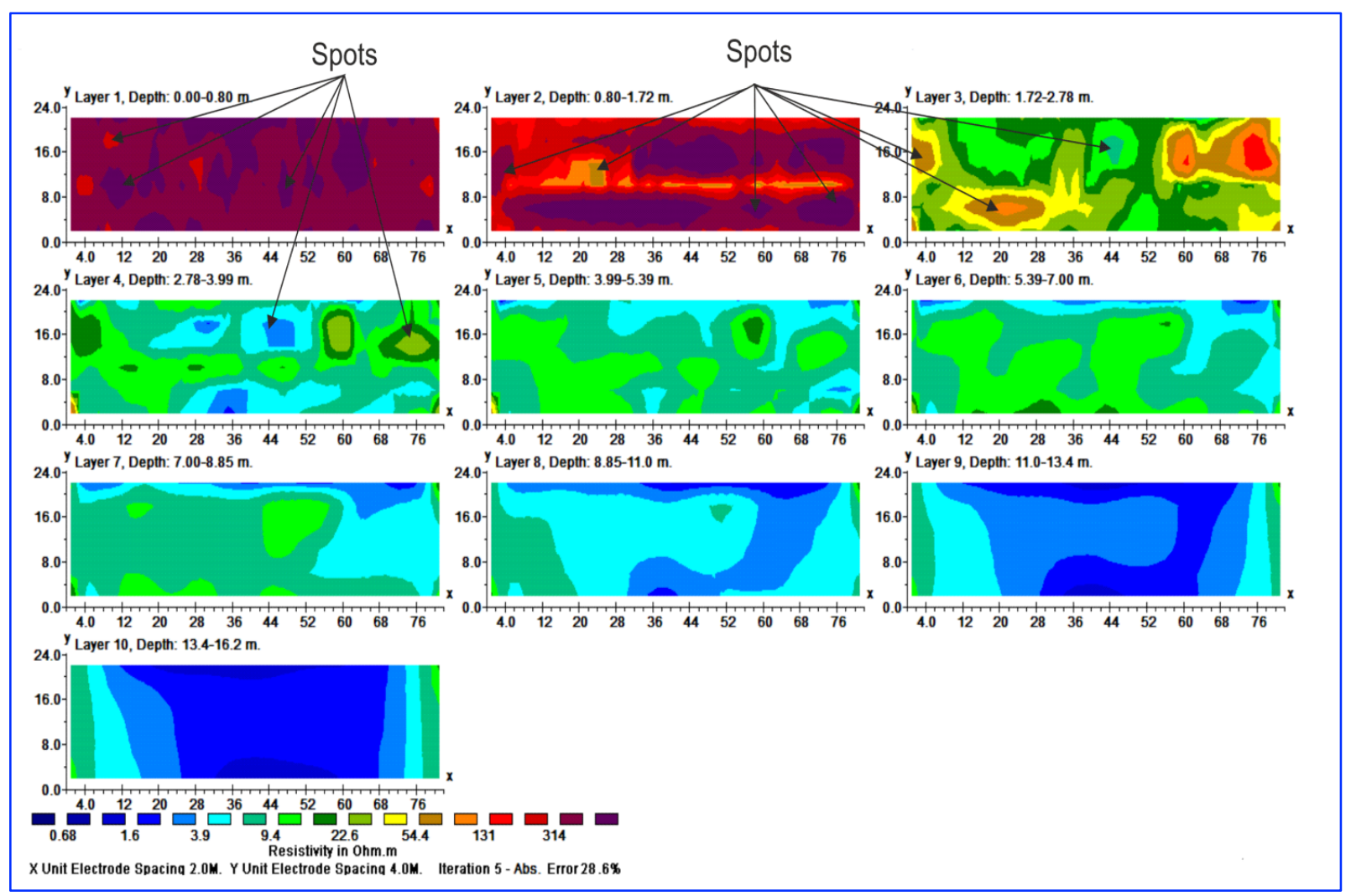

Fig. 7. Horizontal section of the 3D imaging models

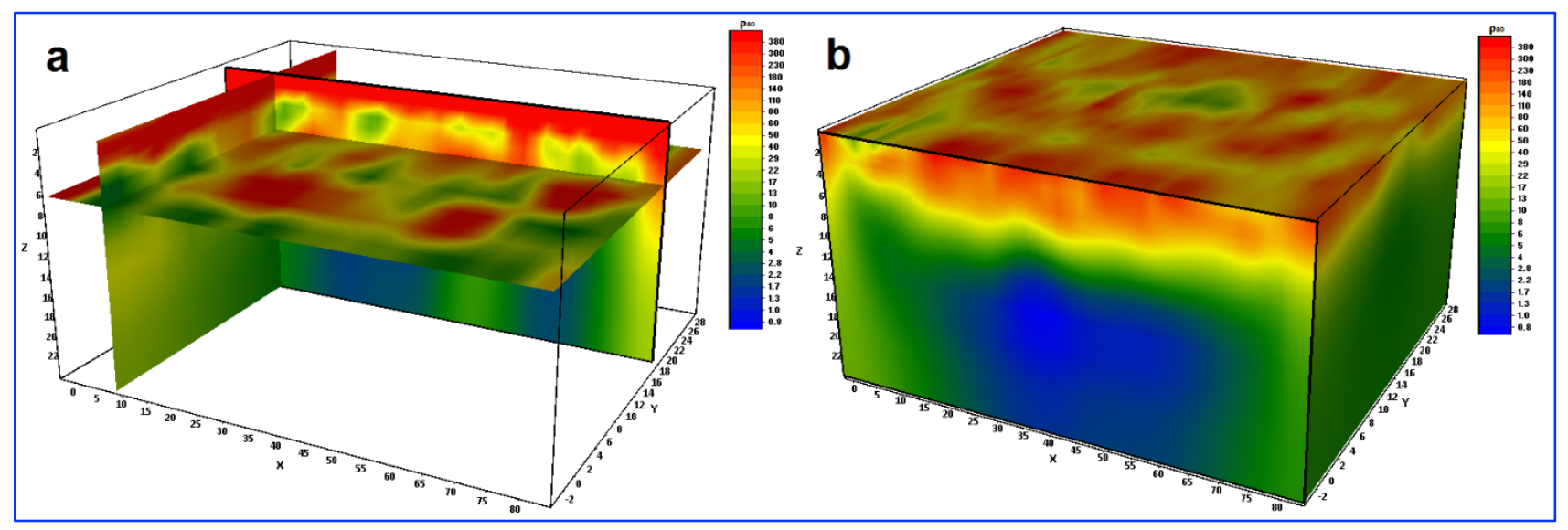

Fig. 8. Three-dimension models show changes in the surface, and subsurface soil components and upper part of the claystone layer: (a) 3D cross-planes, (b) 3D cube.

\section{CONCLUSIONS}

The integration between $2 \mathrm{D}$ and $3 \mathrm{D}$ resistivity imaging models has presented some remarkable results, which can be recapitulated as follows: - 
1. The results of 2D resistivity and $3 \mathrm{D}$ resistivity models that implement using data obtained along 2D lines showed that the thickness of the gypsum soil layer is $2.53 \mathrm{~m}$ in the investigation area.

2. The results of $2 \mathrm{D}$ and $3 \mathrm{D}$ inverse models have presented a good image of the inhomogeneity in the hardness of soil components and the upper part of the claystone layer.

3. The laboratory tests indicating that the gypsum content of three selected samples is equal to 213,232 and $211 \mathrm{~g} / \mathrm{kg}$ respectively.

4. The high resistivity contrast for surfaces soil components and upper part of the claystone layer and result of the chemical test for the soil samples are indicative of an unstable area and can lead to a differential settlement that causes cracks and collapses of constructions.

5. The results show that the lower part of the claystone layer, located at a depth $10 \mathrm{~m}$ approximately, can be used as deep foundations for new buildings.

6. To construct new buildings in this area, there are two solutions; the first one is to remove the gypsum soil and upper part of the claystone layer and construc deep foundations for these buildings. The second is to use the cut-back asphalt that represents the best solution and appropriate ersatz to progress gypsum soil properties.

\section{ACKNOWLEDGMENTS}

The authors are very grateful to the Editor in Chief Prof. Dr. Salih M. Awadh, the Secretary of Journal Mr. Samir R. Hijab and the Technical Editor Dr. Heba S. Al-Mimar for their great efforts and valuable comments.

\section{REFERENCES}

Abdelwahab, H., 2013. Comparison of 2D and 3D resistivity imaging methods in the study of shallow subsurface structures. Greener Journal of Physical Sciences, 3(4): 149-158.

Al-Ebdaa, 2016. Soil investigation report for the new buildings of Diyala university part. 210.

Al-Mamoori, S. K., 2017. Gypsum content horizontal and vertical distribution of An-Najaf and Al-Kufa Cities' soil by using GIS. Basrah Journal for Engineering Sciences, 17: 48-60.

Al-Saoudi, N. K., Al-Khafaji, A. N., and Al-Mosawi, M. J., 2013. Challenging problems of gypseous soils in Iraq. Proceedings of the 18th International Conference on Soil Mechanics and Geotechnical Engineering, Paris. 479-482.

Al-Zubedi, A. S., and Thabit, J. M., 2016. A comparison between 2D azimuthal and 3D resistivity imaging techniques in determining the subsurface fracture zones within Abu-Jir Fault Zone, Southwest Karbala, Central Iraq. Near Surface Geophysics, 14: 401-409. https://doi.org/10.3997/1873-0604.2016020.

Al-Zubedi, A. S., 2015. Principles of Electrical Resistivity Techniques. LAP LAMBERT Academic Publishing Company, Germany, 147 p. 
Amini, A. A., and Ramazi, H., 2017. CRSP, numerical results for an electrical resistivity array to detect underground cavities. Open Geosciences, 9: 13-23. https://doi.org/10.1515/geo-2017-0002

Auken, E., Pellerin, L., Christensen, N. B., and Sørensen, K. I., 2006. A survey of current trends in near-surface electrical and electromagnetic methods. Geophysics, 71(5): G249-G260. https://doi.org/10.1190/1.2335575

Aziz, N. A., Abdulrazzaq, Z. T., and Agbasi, O. E., 2019. Mapping of subsurface contamination zone using 3D electrical resistivity imaging in Hilla city, Iraq. Environmental Earth Sciences, 78: 502.

Claerbout, J. F., and Muir, F., 1973. Robust modeling with erratic data. Geophysics, 38: 826-844.

GCGW, 2001. General Commission for Groundwater, Anbar Project, Data of the Drilled Wells, Iraq.

Hassan, A. A., and Nsaif, M. D., 2016. Application of 2D electrical resistivity imaging technique for detecting soil cracks: Laboratory study. Iraqi Journal of Science, 57: 930-937.

Hassan, A. A., AL-Awsi, M. D., and Al-Obaidi M. M., 2018. Application of 2D electrical resistivity imaging technique for engineering site investigation. Journal of University of Babylon for Pure and Applied Sciences, 26(5): 74-85.

Jassim, S. Z. and Buday, T., 2006. Latest Eocene-Recent Megasequence APII. In: Jassim, S. Z, and Goff, J. C. (eds). Geology of Iraq. Dolin Prague and Moravian Museum, Brno, Czech Republic, pp 169-184.

Kadhim, A. J., 2014. Stabilization of gypseous soil by cutback asphalt for roads construction. Journal of Engineering and Development, 18(1): 46-67.

Loke, M. H., Chambers, J. E., Rucker, D. F., Kuras, O., and Wilkinson P. P., 2013. Recent developments in the direct-current geoelectrical imaging method. Journal of Applied Geophysics, 95: 135-156.

Makhilif, A., Rageh, A. M., Hassan M. A., and Aboud, M. A., 2019. Characteristics and classification of soil potential for agriculture in the tash district within the dry agricultural zone in Anbar Province of Iraq. Plant Archives, 19: 859-869.

Mohammad, W. M. Y., 2012. Soil Resistivity Characterization for Geotechnical Site Investigation. M.Sc. Thesis, Civil Engineering Department, University of Technology, Iraq, 142 p.

Olayinka, A. I., and Yaramanci, U., 2000. Assessment of the reliability of 2D inversion of apparent resistivity data. Geophysical Prospecting, 48: 293-316. https://doi.org/10.1046/j.1365-2478.2000.00173.x

Othman, S., Sarsam, S. I., and Ismail, S. A., 2020. Gypsum and limestone dissolution within Fatha Formation (Middle Miocene) at various pH solutions :A laboratory study, Iraqi Geological Journal, 53 (2B): 71-88.

Sudha, K., Israil, M., Mittal, S., and Rai, J., 2009. Soil characterization using electrical resistivity tomography and geotechnical investigations. Journal of Applied Geophysics, 67(1): 74-79.

Thabit, J. M., and Abed, A. M., 2014. Detection of subsurface cavities by using pole- dipole array (bristow's method)/hit area-western Iraq, Iraqi Journal of Science, 55: 444-453.

Thi Nu, N., Duong, N. T., Son, B. T., Thinh, P. H., 2020. Investigation of salt, alum content in soft soils and their effects on soil properties: case study in coastal areas of Vietnam, Iraqi Geological Journal, 53 (2A): 19-34.

Wisén, R., Christiansen, A. V., Dahlin, T., and Auken, E., 2012. Experience from two resistivity inversion techniques: Applied in three cases of geotechnical site investigation. Journal of Geotechnical and Geoenvironmental Engineering, 134(12): 1730-1742.

Wolke, R., and Schwetlick, H., 1988. Iteratively reweighted least squares algorithms, convergence analysis, and numerical comparisons. SIAM Journal of Scientific and Statistical Computations, 9: 907-921. 